\title{
PETROLOGICAL STRUCTURE OF THE UPPER MANTLE BENEATH THE SOUTH AFRICAN SHIELD
}

Ian D. MacGregor, Department of Geology, University of California,
Davis, California 95616

Suites of ultramafic xenoliths from the Lauwrencia, Bultfontein, Wesselton, Roberts Victor, Monastery, Malibo Matso and Kao kimberlite pipes may be grouped together to characterize the petrology of the upper mantle beneath the South West Africa Kimberley and Lesotho regions.

Ultramafic xenoliths from the Lauwrencia pipe in South West Africa are primarily lherzolites with widely varying ratios of pyroxenes and aluminous phases. Spinel, spinel-garnet and garnet 1 herzolites are all found. A few harzburgites also occur. In the Kimberley area the samples from the Wesselton and Roberts Victor mines are composed primarily of garnet, spinel, and garnet-spinel harzburgites with a few lherzolites showing similar combinations of the aluminous phases. In the Lesotho area xenoliths from the Kao mine are predominantly pure harzburgites with a few spinel, spinel-garnet, and garnet lherzolites. At the Monastery mine spinel-garnet lherzolites have only been found and samples from the Malibo Matsu pipe cluster close to harzburgite. A contrast of the three main regions indicates a significantly wider spread of modal proportions for the samples from South West Africa, and a greater proportion of samples with low clinopyroxene contents for the Kimberley and Lesotho regions. The olivine contents in all localities show no special distributions. All samples are subject to varying degrees of serpentinization with the intensity of serpentinization decreasing in the order South West Africa Kimberley and Lesotho.

Two main textural types occur, a coarse-grained, granular variety and a sheared variety. The coarse-grained granular rocks are composed of large subhedral to rounded olivine crystals interspersed with interstitial to irregular orthopyroxene crystals. Garnet, when present, occurs either as rounded grains or wormy, irregular, intergranular blebs. Similarly spinel is found either as euhedral crystals or as eutectoid-like intergrowths with clinopyroxene or amphibole. Clinopyroxene may occur as rounded grains or more commonly as irregular intergranular crystals. Exsolution textures are common in these rocks. Clinopyroxene, spinel and garnet lamellae exsolve from the orthopyroxene and often form rims or irregular boundaries to large orthopyroxene grains suggesting that much of the intergranular clinopyroxene, garnet and spinel has been exsolved from the orthopyroxene host. Occasionally clinopyroxene grains will also have orthopyroxene exsolution lamellae. Generally the granular textured rocks show little evidence of deformation, although in some cases olivine and orthopyroxene have variable degrees of kink banding. 0livine is always partially serpentinized along a series of veined networks. Phlogopite when present occurs as intergrown flakes, often along with clinopyroxene and spinel in large intergranular areas, or may be associated with the kelyphitic rims characteristically surrounding all the garnets. 
The sheared textured xenoliths are composed of sheared and streaked lenses of deformed orthopyroxene and clinopyroxene in a mosaic of finely granulated olivine. Garnet when present occurs as rounded crystals in the mylonitized olivine groundmass, and is usually surrounded by a rim of kelyphite. The rock has a distinct foliation. Exsolution textures are absent. Serpentinization exploits the rounded boundaries of the olivine grains. Phlogopite is generally absent in these rocks. Garnet is the sole aluminous phase found in the sheared xenoliths, whereas all combinations of aluminous phases occur in the granular textured rocks. Sheared and granular textured samples occur in all the major regions.

The mineral chemistry shows that the South West African xenoliths have olivines, orthopyroxenes and garnets with lower $\mathrm{Mg} / \mathrm{Mg}+\mathrm{Fe}$ ratios than the Kimberley and Lesotho regions. Clinopyroxenes show a similar range of composition, but the Kimberley and South West African samples are slightly more iron rich than the Lesotho samples All minerals in the sheared textured rocks are characteristically higher in $\mathrm{Cr}_{2} \mathrm{O}_{3}$, $\mathrm{TiO}_{2}$ and $\mathrm{Na}_{2} \mathrm{O}$, while garnets and olivine have higher $\mathrm{CaO}$ contents, and the $\mathrm{Mg} / \mathrm{Mg}+\mathrm{Fe}$ ratio of the clinopyroxenes is significantly higher and $\mathrm{CaO}$ lower than the granular textured samples

Assignment of temperatures and pressures to the xenoliths indicates that the samples from all localities have come from a wide range of pressures (depths) and temperatures. It is therefore apparent that the xenoliths are not genetically related to the kimberlite, but accidentally related as fragments of the mantle torn off and transported to the surface. The maximum depth of any fragment from a single locality thus gives the minimum depth below which the kimberlites must have originated. At the Lauwrencia pipe the minimum value is at 150 kilometers, but increases to 170 and 200 kilometers at the Kimberley and Lesotho areas, respectively. The location of the xenoliths indicates a suite of samples originating along a linear profile of increasing temperature with increasing depth or pressure, and leads to the interpretation that the trend marks the location of a paleogeotherm, presumably of Cretaceous age, commensurate with the age of kimberlite extrusion. An anomalous feature which is not commensurate with the simple geotherm interpretation is that the samples with sheared textures mark a linear trend which suggests a sudden steepening of the interpreted geothermal gradient. This phenomenon has also been noticed by Boyd for Lesotho xenoliths and by Johnston for the Jagersfontein pipe. Boyd has interpreted the sudden rise of the geothermal gradient to arise from frictional effects in the low velocity zone during the period of Cretaceous drift. The region with the steep gradients is thus interpreted to mark the Low Velocity Zone, and the sheared nature of the xenoliths from this region is compatible with their deformation during a period of drift. Other possibilities for an increased gradient could be variations in the thermal conductivity such as may arise in a layer of highly deformed rocks. On the basis of these interpretations, the xenoliths thus mark the Cretaceous geotherm beneath the South African Shield, and define the top of the Low Velocity Zone 
A comparison of the geothermal gradients beneath the different 1ocalities studied shows that each mine or pipe gives a different value. The Lauwrencia and Lesotho localities have the highest geothermal gradients, while values from the Kimberley region are significantly lower. The depth to the top of the Low Velocity Region also varies, being at approximately 140 kilometers beneath South West Africa, increasing to 180 kilometers beneath the Lesotho area, and extending to a depth of approximately 200 kilometers beneath the Kimberley area. The general picture suggets that the Cretaceous lithosphere beneath the South African Shield was at a maximum in the Kimberley area and thinned to the east and west. 